\title{
Knowledge Relationship with Maternal Anxiety in Breastfeeding Babies during the Covid-19 Pandemic at UPTD Puskesmas Bawomataluo in 2021
}

\author{
Alfirida Simanungkalit ${ }^{1}$, Anastasia Luahambowo ${ }^{2}$, Lisbet.E.F.Siregar ${ }^{3}$, Dear Sari Br. \\ Purba $^{4}$, Chrismis Novalinda Ginting ${ }^{5}$ \\ 1,2,3,4,5Faculty of Nursing and Midwifery, Universitas Prima Indonesia
}

\begin{abstract}
:
Breast milk is the main food source for babies who contain a variety of vitamins, proteins, and fats. However, with the increase in the Covid-19 pandemic, many mothers do not breastfeed their babies, because they are worried that their babies will contract the Covid-19 virus. This is due to the lack of information obtained by mothers, that the Covid-19 virus cannot be transmitted through breast milk. This study aims to find out the relationship of knowledge with maternal anxiety in breastfeeding in infants during the Covid-19 pandemic. This type of quantitative research with an analytical descriptive approach, conducted at UPTD Bawomataluo, November to December 2021. A population of 61 nursing mothers, a large determination of the total sampling sample. Univariate data analysis and bivariate analysis, Chi-Square test, a significant level of 0.05 . The majority of respondents had less knowledge than 43 respondents $(70.2 \%)$. The majority of respondents had a severe anxiety level of 31 respondents $(50.8 \%)$. The results of bivariate analysis of knowledge relationship and anxiety level obtained value $p$-value $=0.000<=0.05$. Concluded, it can be concluded that there is a meaningful relationship between the level of knowledge and anxiety levels of breastfeeding mothers in the Covid-19 pandemic.
\end{abstract}

Keywords:

knowledge; breastfeeding; anxiety; covid-19

\section{Introduction}

Breast milk is the main food source for babies (Masyarakat, Siregar, and Septian 2004), which contains a wide variety of vitamins, proteins, and fats (Ariyanti et al. 2021). World Health Organization (WHO), recommends exclusive breastfeeding for the first 6 months of life, followed by continuing breastfeeding with proper companion foods for up to 2 years and beyond (Novianti and Rizkianti 2014). In 2018, the percentage of breastfeeding worldwide was very low, reaching only $41 \%$ still far from 53\% (Kemenkes RI 2018). Based on data from the Healthy Family Application in 2020 in South Nias Regency, exclusive breast milk coverage is still low at $50.73 \%$. Likewise with the scope in the working area of UPTD Bawomataluo Health Center which covers 17 villages, from the data obtained that the exclusive breast milk coverage is still relatively low.

Sihombing (2020) state that Covid-19 pandemic caused everyone to behave beyond normal limits as usual. The outbreak of this virus has an impact especially on the economy of a nation and Globally (Ningrum, 2020). The problems posed by the Covid-19 pandemic which have become a global problem have the potential to trigger a new social order or reconstruction (Bara, 2021). But at the time of the Covid 19 pandemic, some breastfeeding mothers feel afraid and anxious to give breast milk to their babies. One of the factors that 


\section{Britain International of Exact Sciences (BIoEx) Journal \\ ISSN: 2686-1208 (Online), 2686-1216 (Print) \\ Vol. 4, No. 1, January 2022, Page: 56-62 \\ Email:bioexjournal@gmail.com}

influence a mother's anxiety to breastfeed is the lack of information obtained by the mother about how to breastfeed during the pandemic period (Ratih Suryaman 2021). They consider that coronavirus disease can be transmitted through breast milk given to the baby. In fact, according to the World Health Organization, the Covid-19 virus is not transmitted through breast milk, but direct contact with the mother while breastfeeding the baby. WHO and UNICEF recommend that mothers who confirm COVID-19 remain breastfeeding by strict health protocols (Sulistiyowati, Amalia, and Irawan 2021). Research results (Ratih Suryaman 2021), In Bubulak Bogor Village, stated that the majority of respondents had less knowledge to increase severe anxiety in the way of breastfeeding in the covid pandemic. In the results of the initial survey, some breastfeeding mothers who visited UPTD Bawomataluo Health Center stated that they did not give breast milk to their babies because of a lack of knowledge related to the transmissions of the Covid-19 virus. This study aims to find out the relationship of knowledge with maternal anxiety in breastfeeding in infants during the covid-19 pandemic.

\section{Review of Literature}

Breast milk contains many antibody substances that make the baby's immune system stronger in fighting various kinds of bacteria and viruses (Puspitasari and Syahrul 2015); (Nosa and Anindita 2021). Breast milk is also an ideal mixture of antibodies, vitamins, and immune factors so it is currently needed to improve children's immunity (Williams et al., 2020). Anxiety is a normal feeling that humans have because when feeling anxious humans are resuscitated and reminded that there is a situation of danger that threatens. But when anxiety that was normal and can be controlled turns into anxiety that is continuous and cannot be controlled, it will interfere with daily activities (Dewi and Fauziah 2018). Anxiety is divided into four levels, namely mild anxiety, moderate anxiety, severe anxiety, and severe anxiety. The level of anxiety each individual feels is different, influenced by how the individual adjusts and copes with situations that trigger anxiety (Suhardi and Aiyub 2018); (Gheralyn Regina Suwandi 2020).

\section{Research Methods}

This type of research is quantitative research with an analytical decryptive approach. Research site at UPTD Bawomataluo, November to December 2021. The study population of 61 nursing mothers, a large determination using total sampling. The data collection used the Hamilton Rating Scale for Anxiety questionnaire for anxiety variables and 15 questions about the knowledge of breast milking mothers during the pandemic.

Table 1. Research Variables and Operational Definition

\begin{tabular}{|c|c|c|c|c|c|}
\hline No & Variabel & Operational & $\begin{array}{l}\text { Measuring } \\
\text { Instrument }\end{array}$ & Measured Results & Scale \\
\hline 1 & Level of knowledge & $\begin{array}{l}\text { Everything that } \\
\text { the mother knows } \\
\text { in breastfeeding } \\
\text { during the } \\
\text { pandemic }\end{array}$ & Questionnaire & $\begin{array}{l}\text { Good: if the value } \\
76-100 \% \\
\text { Enough: if the } \\
\text { value } 56-75 \% \\
\text { Less: if the value < } \\
56 \%\end{array}$ & Ordinal \\
\hline 2 & Anxiety Level & $\begin{array}{l}\text { Everything that } \\
\text { you feel and show } \\
\text { about anxiety in } \\
\text { the Covid-19 } \\
\text { pandemic }\end{array}$ & Questionnaire & $\begin{array}{l}\text { Not worried: }<=14 \\
\text { Mild anxiety: } 14-20 \\
\text { Anxious being: } 21- \\
27 \\
\text { Severe anxiety: } 28- \\
41 \\
\text { Panic: } 42-56\end{array}$ & Ordinal \\
\hline
\end{tabular}


The data analysis used in this study is, univariate analysis and bivariate analysis. With a Chi-Square test with a significant level of 0.05 .

\section{Discussion}

\subsection{Results}

\section{a. Univariat Analysis}

Based on the results of research conducted with the number of 61 respondents, with the title of maternal knowledge and anxiety in breastfeeding during the covid-19 pandemic at UPTD Bawomataluo Health Center in 2021, the results of the univariate analysis in this study were conducted to describe the characteristics of respondents obtained from the following data:

Table 2. Characteristics of Distribution of Respondents According to Education and Age of Mothers in Breastfeeding in Infants during the Covid-19 Pandemic

\begin{tabular}{lcc}
\hline Characteristics of Respondent Distribution & Sum(n) & Percentage(\%) \\
\hline Education & & \\
\hline SD (Primary school) & 4 & 6,6 \\
\hline SLTP (First-rate advanced school) & 28 & 45,9 \\
\hline SLTA (Top-level advanced schools) & 24 & 39,3 \\
\hline College & 5 & 8,2 \\
\hline Sum & $\mathbf{6 1}$ & $\mathbf{1 0 0}$ \\
\hline Age & & 26.2 \\
\hline 19-27 Years & 16 & 57,4 \\
\hline 28-34 Years & 35 & 16,4 \\
\hline 35-40 Years & 10 & $\mathbf{1 0 0}$ \\
\hline Sum & $\mathbf{6 1}$ &
\end{tabular}

Based on the table above it can be concluded that the majority of respondents educated SLTP as many as 28 people (45.9\%), SLTA as many as 24 people $(39.3 \%)$, college as many as 5 people $(8.2 \%)$, and a minority of elementary-educated respondents, which is as many as 4 people $(6.6 \%)$. Age, the majority of respondents in the age range of 28-34 years as many as 35 people (57.4\%), the range of $19-27$ years as many as 16 respondents $(26.2 \%)$, and minorities in the age range of $35-40$ years as many as 10 respondents $(16.4 \%)$.

Table 3. Description of Maternal Knowledge in Breastfeeding Babies during Covid-19 at UPTD Puskesmas Bawomataluo in 2021

\begin{tabular}{llc}
\hline Knowledge & Sum(n) & Percentage \\
\hline Low & 43 & 70,5 \\
\hline Enough & 15 & 24,6 \\
\hline Good & 3 & 4,9 \\
\hline Sum & $\mathbf{6 1}$ & $\mathbf{1 0 0}$
\end{tabular}

Based on the table above it can be concluded that the data of respondents' knowledge in breastfeeding children during the COVID-19 pandemic the majority of respondents who have less knowledge as many as 43 respondents $(70.2 \%)$, than respondents who have enough knowledge as many as 15 respondents $(24.6 \%)$, and respondents have good knowledge as much as 3 respondents $(4.9 \%)$. 
Table 4. Description of Maternal Anxiety Levels in Breastfeeding Infants during the Covid 19 Pandemic at UPTD Puskesmas Bawomataluo in 2021

\begin{tabular}{llc}
\hline Anxiety & Sum(n) & Percentage $\mathbf{0} \mathbf{0})$ \\
\hline Light & 6 & 9,8 \\
\hline Keep & 24 & 39,3 \\
\hline Heavy & 31 & 50,8 \\
\hline Sum & $\mathbf{6 1}$ & $\mathbf{1 0 0}$ \\
\hline
\end{tabular}

Based on the table above it can be concluded that infant respondent anxiety data were breastfed during the COVID-19 pandemic, the majority of respondents who had a mild worry as many as 6 respondents $(9.8 \%)$, who had moderate anxiety as many as 24 respondents $(39.3 \%)$, and respondents who had severe anxiety as many as 31 respondents $(50.8 \%)$.

\section{b. Bivariate Analysis}

Bivariate analysis aims to determine the relationship between free variables (categories) and bound variables (categories). Bivariate analysis in this study was conducted using Chi Square during the COVID-19 pandemic at UPTD Puskesmas Bawomataluo in 2021 to see if there is a link between knowledge and breastfeeding mother anxiety.

Table 5. Knowledge Relationship with Maternal Anxiety in Breastfeeding Babies during the COVID-19 Pandemic at UPTD Puskesmas Bawomataluo

\begin{tabular}{|c|c|c|c|c|c|c|}
\hline \multicolumn{4}{|c|}{ Anxiety } & Total & \multirow[b]{2}{*}{ df } & \multirow{2}{*}{$\begin{array}{l}\text { Asymp. Sig. } \\
\text { (2-sided) }\end{array}$} \\
\hline Knowledge & Light & Sedang & Berat & & & \\
\hline Low & 0 & 12 & 31 & 43 & \multirow{4}{*}{1} & \multirow{4}{*}{, 000} \\
\hline Enough & 3 & 12 & 0 & 15 & & \\
\hline Good & 3 & 0 & 0 & 3 & & \\
\hline Total & 6 & 24 & 31 & 61 & & \\
\hline
\end{tabular}

Based on the results of chi-square analysis tests at a significant level at 95\% showed that there is a significant association between the knowledge of breastfeeding babies during the covid-19 pandemic and maternal anxiety. This is indicated by p-value $=0.000<=0.05$, thus $\mathrm{HO}$ is rejected $\mathrm{Ha}$ is accepted.

\subsection{Discussion}

The authors explained from the results of the study on the relationship between maternal knowledge and anxiety in breastfeeding during the covid-19 pandemic at UPTD Bawomataluo Health Center in 2021 with 61 respondents as a sample:

\section{a. Characteristics of Breastfeeding Mothers}

The results of the above educational characteristics were obtained by elementary school with the number of 4 respondents (6.6\%), SLTP with the number of 28 (45.9\%), SLTA 24 respondents $(39.3 \%)$ and universities with 5 respondents. Education can motivate itself by influencing behavior and thus plays a role in healthy development. The higher a person's level of education, the easier it is to receive information and the more knowledge that can be obtained. College can influence a person, one of whom can accept ideas, ideas and materials more quickly (Notoatmodjo 2013). From the age characteristics of respondents above obtained the age of 19-27 years with the number of 16 respondents $(26.2 \%), 29-34$ years with the number of 35 respondents (57.4\%), 35-40 years with the number of 10 respondents $(16.4 \%)$. 
Age greatly affects the mother's condition and is associated with pregnancy, childbirth, and lactation. The age of the mother is very influential on how the mother takes decisions to take care of her health. The older we get, the more knowledge and experience our mothers get (Vivi Budiart 2018).

\section{b. Knowledge of breastfeeding mothers}

The distribution of maternal knowledge frequency in nursing infants during the covid19 pandemic was reviewed from table 3.2 some categories of less knowledgeable respondents, namely 43 people (70.5\%). These findings are in line with the research (Ratih Suryaman 2021), entitled "Knowledge Relationship with Anxiety in Breastfeeding Mothers During the Covid19 Pandemic" as many as 42 respondents and there were 27 participants $(64.3 \%)$ with less knowledge. According to (Mubarak WI 2007), many factors affect knowledge such as education, age, etc. Low education will hinder the development of attitudes towards new values. The older a person is the more mature maturity and strength in thinking and working. In terms of community trust, adults are more trusted than those who are immature. It comes from the experience and maturity of the soul. From the results of the survey, it can be concluded that $43(70.5 \%)$, out of 61 respondents have less knowledge. It has to do with many factors, one of which is the COVID-19 pandemic situation, the problem of the availability of information with limited public facilities to obtain information.

Based on the results of the breastfeeding maternal anxiety survey during the COVID19 pandemic, it was found that 31 out of 61 respondents in the category of severe anxiety in breastfeeding during the COVID-19 pandemic were found to be in the COVID-19 pandemic. According to (Pratiwi, Widianti, and Solehati 2017), several factors that cause anxiety, namely predisposing factors and precipitation factors. The predisposition factor consists of traumatic, emotional conflict, frustration, and physical impairment. Trigger factors include threats to physical integrity and threats to self-esteem including external, internal sources, and knowledge. Anxiety is closely related to anxiety and helplessness. Anxiety is a person's emotional experience, and this emotional state has no particular purpose and is experienced subjectively. Anxiety status is defined as the appearance of unpleasant emotions when faced with demands or dangers. Anxiety is different from fear. Fear is an intellectual assessment of a dangerous thing that is clear, certain, and realistic about what it is facing, anxiety is an emotional reaction to that judgment, and the judgment that occurs is the anxiety of the individual itself (Alfiyanti, Kunci, and Pustaka 2015). The results of the study, the distribution of anxiety is known that of 61 respondents, 31 respondents experienced severe anxiety. The results of this study are in line with the research (Ratih Suryaman 2021), Of the 42 respondents studied, the majority of respondents experienced severe anxiety, which was as many as 25 people (59.5\%). Anxiety occurs because the more news about COVID-19, the more spread, and the concerns of workers who help with childbirth do not use PPE (masks, masks, and masks) are afraid to leave the house during Covid-19 and can not afford nutritious food. Based on the findings of existing research and theories, researchers concluded that one of the factors that make mothers experience anxiety in breastfeeding babies, due to lack of information related to Covid-19 transmission.

\section{c. The Relationship between Knowledge and Maternal Anxiety in Breastfeeding during the Covid-19 Pandemic}

Based on the results of the study found a relationship between knowledge and anxiety while breastfeeding babies during the Covid-19 pandemic. There is a significant association between knowledge and maternal anxiety while breastfeeding a baby during the Covid-19 pandemic characterized by a p-value $=0.000<=0.05$ with X2 count $=52,488$. Based on the above data it can be concluded that during the COVID-19 pandemic there was a relationship 
between breastfeeding knowledge and maternal anxiety, this is indicated by a value of $\mathrm{P} 0.000$ $<0.05$ then $\mathrm{Ha}$ was accepted and Ho was rejected.

\section{Conclusion}

From the results and analysis of the study can be concluded, the majority of respondents have less knowledge, and the majority of respondents experience severe anxiety in terms of breastfeeding during the Covid-19 pandemic. Based on Chi-square analysis there is a relationship between maternal knowledge and maternal anxiety during breastfeeding during the pandemic with a value of $\mathrm{p}=0,000<0.005$, at UPTD Bawomatalo Health Center in 2021.

\section{References}

Alfiyanti, Dera, Kata Kunci, and Daftar Pustaka. 2015. "Pengaruh Terapi Bermain Merangkai Manik-." 22.

Ariyanti, Eri, Wirawan Fadly, muhamad kkhoirul Anwar, and Titah Sayekti. 2021. "Jurnal Tadris IPA Indonesia." Analisis Kemampuan Membuat Kesimpulan Menggunakan Model Contextual Teaching and Learning Berbasis Education for Sustainable Development 1(2):99-107.

Bara, A., et.al. (2021). The Effectiveness of Advertising Marketing in Print Media during the Covid 19 Pandemic in the Mandailing Natal Region. Budapest International Research and Critics Institute-Journal (BIRCI-Journal) Vol 4 (1): 879-886.

Dewi, Inggriane Puspita, and Diana- Fauziah. 2018. "Pengaruh Terapi Seft Terhadap Penurunan Tingkat Kecemasan Pada Para Pengguna Napza." Jurnal Keperawatan Muhammadiyah 2(2).

Gheralyn Regina Suwandi. 2020. "Hubungan Tingkat Pengetahuan Dengan Tingkat Kecemasan Terhadap Covid- 19 Pada Remaja Di SMA Advent Balikpapan." Malahayati Nursing Journal 2(4):677-85.

Kemenkes RI. 2018. "Hasil Riset Kesehatan Dasar Tahun 2018.” Kementrian Kesehatan RI 53(9):1689-99.

Masyarakat, BGK, Mhd. arifi. Siregar, and Rian Septian. 2004. "Pemberian Asi Ekslusif Dan Faktor-Faktor Yang Mempengaruhinya Mhd. Arifin Siregar.” Pemberian Asi Ekslusif Dan Faktor-Faktor Yang Mempengaruhinya.

Mubarak WI. 2007. Promosi Kesehatan. Yogyakarta: Graha Ilmu.

Ningrum, P.A., Hukom, A., and Adiwijaya, S. (2020). The Potential of Poverty in the City of Palangka Raya: Study SMIs Affected Pandemic Covid 19. Budapest International Research and Critics Institute-Journal (BIRCI-Journal) Vol 3 (3): 1626-1634.

Nosa, Korespondensi, and Septiana Anindita. 2021. "Aktivitas Antibakteri Lactobacillus Paracasei Asal Air Susu Ibu (ASI) terhadap Bakteri Patogen Antibacterial Activity of Lactobacillus Paracasei." Biomedika 13(1):36-47.

Notoatmodjo, S. 2013. Pendidikan Dan Perilaku Kesehatan. Jakarta: Rineka Cipta.

Novianti, and Anissa Rizkianti. 2014. "Pemberian Asupan Prelakteal sebagai Salah Satu Faktor Tekstil di Jakarta Prelacteal Feeding Intake as One Factor That Led to The Failure of Exclusive Breastfeeding in Textile Industry Workers in Jakarta." (April).

Pratiwi, Siti Rahmiati, Efri Widianti, and Tetti Solehati. 2017. "Gambaran Faktor-Faktor Yang Berhubungan Dengan Kecemasan Pasien Kanker Payudara Dalam Menjalani Kemoterapi.” Jurnal Pendidikan Keperawatan Indonesia 3(2):167.

Puspitasari, Dian Eka, and Fariani Syahrul. 2015. "Faktor Risiko Pneumonia Pada Balita Berdasarkan Status Imunisasi Campak Dan Status ASI Eksklusif." Jurnal Berkala Epidemiologi 3(1):69-81. 
Ratih Suryaman. 2021. "Hubungan Pengetahuan Dengan Kecemasan Ibu Dalam Pemberian Asi pada Bayi dimasa Pandemi Covid 19." 9(Mei):1-23.

Sihombing, E.H., and Nasib. (2020). The Decision of Choosing Course in the Era of Covid 19 through the Telemarketing Program, Personal Selling and College Image. Budapest International Research and Critics Institute-Journal (BIRCI-Journal) Vol 3 (4): 28432850.

Suhardi, and Aiyub. 2018. “Tingkat Kecemasan Mahasiswa Sarjana Keperawatan Yang Mengikuti Ujian Computer Based Test (Cbt) the Anxiety Level of Nursing Undergraduate Student Who Take Computer Based Test (Cbt).” JIM Fkep 3(4).

Sulistiyowati, Amirul Amalia, and Dwi Dianita Irawan. 2021. "Peningkatan Pengetahuan Kader Kesehatan Melalui Promosi Asi Eksklusif Dimasa Pandemi Covid-19." JMM (Jurnal Masyarakat Mandiri) 5(4):1-8.

Vivi Budiart. 2018. "Hubungan Karakteristik Ibu Dan Dukungan Suami Dengan Tingkat Pengetahuan Ibu Hamil Tentang Tanda Bahaya Kehamilan." Journal of Issues in Midwifery 2(1):1-18. 